\title{
ВОЗМОЖНОСТЬ ОПТИМИЗАЦИИ ВНУТРИАПТЕЧНОГО ИЗГОТОВЛЕНИЯ ТВЕРДЫХ ЛЕКАРСТВЕННЫХ ФОРМ ЗА СЧЕТ ПРИМЕНЕНИЯ ЖЕЛАТИНОВЫХ КАПСУЛ
}

\section{О.А. Гречишкина' А.Ю. Петров ${ }^{1}$}

${ }^{1}$ Кафедра фармации и химии, Уральский государственный медицинский университет,
620028, Российская Федерация, Екатеринбург, ул. Репина, 3.
Кафедра органической и биомолекулярной химии,
Уральский федеральный университет имени первого Президента России
Б.Н. Ельцина, 620002, Российская Федерация, Екатеринбург, ул. Мира, 19.
${ }^{3}$ Институт органического синтеза им. И.Я. Постовского
Уральского отделения Российской академии наук,
620137, Российская Федерация, Екатеринбург, ул. Софьи Ковалевской, дом 22/20.

DOI: 10.19163/MedChemRussia2021-2021-357

E-mail:67kuzy@bk.ru

Использование коммерчески доступных капсульных машин без раскрытия капсул может привести к сокращению скорости фасовки порошков и повысить привлекательность данной формы для потребителя.

Для моделирования процесса заполнения капсул использовали вспомогательное вещество лактозу для прямого прессования и для грануляции (марок 60 и 200 меш соответственно), выбранных как эталон порошков разной степени измельчения. Проводили определение насыпной плотности без уплотнения и после уплотнения согласно общепринятой методики [1]. Также рассматривали плотности четырех прописей порошков Антригриппин. После сравнения насыпной плотности марок модельных порошков 60 и 200 меш, очевидна схожесть показателей лактозы и порошков антигриппина. Далее производили фасовку порошков с использованием коммерчески доступной модели полуавтоматической капсульной машины №0, 00 (OLOEY, Китай). Максимальное наполнение при уплотнении превышало расчетные значения и не зависело от исполнителя. При использовании входящего в комплект уплотнителя достигается подпрессовывание порошка в капсуле.

Продолжительность наполнения капсул с уплотнением составило 5-8 минут. Время на укомплектовку пластины для крышечек и закрытия капсул 3-6 минут. Количество брака составило от 3 до 6\%

\section{Литература}

[1] Государственная фармакопея Российской Федерации XIV издание. 2018. T2. 3262 с. 